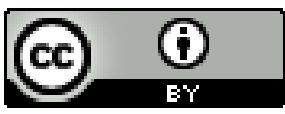

\title{
A TRANSMISSÃO ORAL DE VALORES ANCESTRAIS NO CANDOMBLÉ COMO PRÁTICA EDUCATIVA
}

\author{
Eudaldo Francisco dos santos Filho ${ }^{1}$ \\ Janaína Bastos Alves ${ }^{2}$
}

\begin{abstract}
Resumo: Este trabalho consiste em uma sucinta reflexão sobre as práticas e conhecimentos ancestrais do Candomblé que contribuem com a educação e com a formação de valores humanos na vida dos seus adeptos e dos sujeitos com quem se relacionam. Na construção deste estudodiscorremos sobre a educação em seu acontecimento formal, não-formal e informal, bem como sobre a formação de valores dos indivíduos dentro destas práticas. Através de revisão bibliográfica discutimos sobre a educação e sua apropriação pelos grupos envolvidos na referida instituição religiosa. Discutimos brevemente sobre o advento do Candomblé como consequência da presença dos africanos no Brasil, e, a partir destes fatores, constatamos que existe importante processo formador de valor na realização da religião destacada. Concebemos assim, que existem possibilidades de uso de saberes gerados na ritualística candomblecista que podem contribuir positivamente no processo de educação formal.
\end{abstract}

Palvras-Chave: Ancestralidade; Candomblé; Educação; Formação de valores; Oralidade.

\section{THE ORAL TRANSMISSION OF ANCESTRAL VALUES IN CANDOMBLÉ AS EDUCATIONAL PRACTICE.}

\begin{abstract}
This work consists of a succinct reflection on Candomblé's ancestral practices and knowledge that contribute to education and the formation of human values in the lives of its supporters and the subjects with whom they relate. In the construction of this study we discuss about education in its formal, non-formal and informal, as well as about the formation of values of individuals within these practices. Through literature review we discuss about education and its appropriation by the groups involved in that religious institution. We briefly discuss the advent of Candomblé as a consequence of the presence of Africans in Brazil, and from these factors we find that there is an important value-forming process in the realization of the outstanding religion. Thus, we conceive that there are possibilities of using knowledge generated in Candomblecist ritualistic that can contribute positively to the process of formal education.
\end{abstract}

Key-words: Ancestry; Candomblé; Education; Generation of values; Orality.

\footnotetext{
${ }^{1}$ Doutor em Difusão do Conhecimento, professor da Universidade do Estado da Bahia - Departamento de Ciências Exatas e da Terra; Perito Técnico do Departamento de Polícia Técnica. Coordenador do LBI Multidisciplinar do Laboratório de Biometria e Imagem UNEB. eudaldofilho@gmail.com

${ }^{2}$ Mestre em Educação - Universidade do Estado da Bahia e pesquisadora do LBI - UNEB; professora do ensino fundamental da rede privada. janainabaeducadora@gmail.com
} 

PRÁCTICA EDUCATIVA.

Resumen: Este trabajo consiste en una breve reflexión sobre lasprácticasancestrales y elconocimiento de Candomblé que contribuyen a laeducación y laformación de valores humanos enla vida de sus seguidores y lossujetosconquienes se relacionan. Enlaconstrucción de este estudio discutimos sobre laeducaciónensu forma formal, no formal e informal, así como sobre laformación de valores de losindividuos dentro de estas prácticas. A través de larevisión de literatura, discutimos sobre laeducación y suapropiación por los grupos involucrados enesainstitución religiosa. Discutimos brevemente eladvenimiento de Candomblé como consecuencia de la presencia de africanos en Brasil, y de estosfactores encontramos que hayun importante proceso de formación de valor enlarealización de lareligiónsobresaliente. Por lo tanto, concebimos que existenposibilidades de utilizar elconocimientogeneradoenel ritualismo candomblecista que puede contribuir positivamente al proceso de educación formal.

Palabras Clave: Ascendencia; Candomblé; Educación; Valoración; Oralidad.

\section{LA TRANSMISSION ORALE DES VALEURS ANCESTRALES À CANDOMBLÉ COMME PRATIQUE ÉDUCATIVE.}

Sommaire: $\mathrm{Ce}$ travail consiste en uneréflexionsuccinctesur les pratiquesetconnaissancesancestrales de Candomblé qui contribuent à l'éducation et à la formation des valeurshumainesdans la vie de ses partisans et des sujets avec lesquelsils se rapportent. Dans la construction de cetteétude, nous discutons de l'éducationdansses aspects formel, non formel et informel, ainsi que de la formation des valeurs des individus au sein de cespratiques. À traversune revue de la littérature, nous discutons de l'éducation et de son appropriation par les groupesimpliquésdanscette institution religieuse. Nousdiscutonsbrièvement de l'avènement de Candomblé commeconséquence de laprésencedesAfricainsauBrésil, et à partir de cesfacteurs, nousconstatonsqu'il existe unimportantprocessus de création de valeurdanslaréalisation de lareligionexceptionnelle. Ainsi, nousconcevonsqu'il existe despossibilités d'utilisationdesconnaissancesgénéréesdanslerituelcandomblistequipeuventcontribuerpositivemen tauprocessus d'éducationformelle.

Mots Clés: Ascendance; Candomblé; Éducation; Évaluation; Oralité.

\section{INTRODUÇÃO}

O processo de educação é de singular importância na vida dos seres humanos, e este é um fator decisivo nas sociedades em geral, inclusive, pela sua abrangência que não se limita a espaços físicos, fazendo valer a convergência de todas as formas de construção e difusão de conhecimento. Por isso mesmo, nosso trabalho se ocupa em considerar a educação fora da escola como de extrema relevância, sendo vivida em diversos ambientes, como realização natural dos indivíduos e das civilizações. Existem práticas educativas que acontecem fora da instituição escolar, empiricamente, oriundas de conhecimentos ancestrais, de vivências cotidianas, anteriores à própria fundação da escola, e que contribuem para a educação e formação de valores no indivíduo. Práticas 
estas, que acontecem em organizações comunitárias, instituições religiosas e outros âmbitos sociais, não necessariamente núcleos escolares, mas que por transmitir conhecimentos e ajudarem na formação de valores humanos, resultam em contribuição informal para a educação dos indivíduos. Destacamos que nosso estudo foca na contribuição da educação do Candomblé, pois, concebemos que suas práticas podem favorecer inclusive a educação formal dos indivíduos.

Entendendo que a educação está em toda parte onde há vida humana, conforme Brandão (1997) e Freire (1999), percebemos que nos Terreiros de Candomblé sua ocorrência é cotidiana, sendo transmitidos aos seus adeptos os ensinamentos dos saberes ancestrais que são validados e repercutidos nas comunidades em que estão inseridos. São transmissões de conhecimentos que não constam em livros, fazendo parte das memórias dos seus representantes, e, vale destacar, são praticados através da oralidade, tradicional prática na religião de matriz africana. Quanto a isto Silveira (2004, p. 22) declara: "Como sociedade de tradição oral, no terreiro, todo o conhecimento é processado verbalmente, cada geração transmitindo à outra um patrimônio simbólico.”.

É importante salientar que o processo de educação do ser humano pode ocorrer através de fenômenos distintos e em espaços dos mais diversos, em situações de casa junto à família, na rua com a comunidade, nas empresas, nas associações, no esporte, nos meios de comunicação e nas religiões. Tendo algumas dessas instituições a proposta intencional de educação no seu sentido mais abstrato e até naturalmente, mesmo sem ter essa atribuição formalizada. Assim ocorre com o Candomblé, assumindo o papel de formação educacional, reafirmando relevante incumbência a cada ato ritual, ou celebração, começando no processo de iniciação dos seus adeptos. Essas práticas educativas e de transmissão de valores repercutem nos indivíduos com quem a religião mantém relação, iniciados ou não. Por este motivo, concebemos indispensável discorrer brevemente sobre a educação em sua definição e ocorrência, e conseguinte sobre a formação de valores humanos para que, enfim, tratemos da religião Candomblé e sua participação nestas duas realizações humanas.

\section{EDUCAÇÃO}

A discussão sobre a educação acompanha a humanidade, e considera-se que sua influência, quer seja de caráter formal, informal ou não-formal, interfere na formação do 
caráter do indivíduo, em seu comportamento e em seu comprometimento e postura diante o mundo em que vive. Sua relevância começa desde o início de vida, pois, é onde se inicia o processo de transmissão e construção de conhecimentos, de valores morais e culturais do ser humano.

Recorrendo ao Houaiss (2009, p. 722), veremos sua definição etimológica, que nos revelará a educação como ação ou efeito de educar (-se), ensino, instrução, etc. Então, compreendemos que esta, é o ato de instruir, ensinar, desenvolver as capacidades humanas, visando à integração social, a relação com o mundo. Ainda constam em seus significados, adjetivos como delicadeza e civilidade, ou seja, as boas maneiras, os bons modos do comportamento de determinada pessoa. Diante disto, constatamos a ação e relevância da educação no desenvolvimento humano, sua implicação física, sensorial, intelectual e moral. O contato com um processo de educação influencia na cognição, no desenvolvimento motor, psíquico e social do indivíduo por isso, são constantes e sistemáticas as discussões sobre seu funcionamento, método e ação.

Espera-se que uma pessoa que tenha tido contato com algum processo educacional, tenha condições de interagir com alguma desenvoltura com o outroe o mundo que o cerca. Para Piaget (1998, p. 33), “A educação é, por conseguinte, não apenas uma formação, mas uma condição formadora necessária ao próprio desenvolvimento natural". Concebemos então que ao educar um indivíduo estamos colaborando com seu desenvolvimento pleno. Para Freire (1999, p. 43), "Não há educação fora das sociedades humanas, e não há homem no vazio", por isso mesmo, tem sua ocorrência em várias esferas do convívio humano. O homem vive a educação permanentemente, em todas as suas relações e situações cotidianas.

Com a perspectiva de educação acontecendo além da escola, é importante que saibamos o que de fato diz respeito à educação não-formal e educação informal, verificando suas definições, suas atuações, e colaborações para o desenvolvimento do ser humano. Neste sentido temos a informação de Gadotti (2005, p. 02) que esclarece, "usualmente define-se a educação não formal por uma ausência, em comparação com a escola, tomando a educação formal como único paradigma, como se a educação formal escolar também não pudesse aceitar a informalidade, o "extraescolar".”.

Apesarda contribuição de Gadotti e de relativos estudos sobre a educação fora da instituição escolar, observamos que o entendimento a respeito disto ainda não está consolidado. Talvez, haja pouco espaço na sociedade para reflexão acerca dessa 
realidade, ou, até mesmo o fato de as pessoas não atentarem em relação a essa prática educativa, mesmo estando inserida nela. Ainda em Gadotti, temos:

A educação formal tem objetivos claros e específicos e é representada principalmente pelas escolas e universidades. Ela depende de uma diretriz educacional centralizada como o currículo, com estruturas hierárquicas e burocráticas, determinadas em nível nacional, com órgãos fiscalizadores do Ministério da Educação. A educação não-formal é mais difusa, menos hierárquica, menos burocrática. Os programas de educação não-formal não precisam necessariamente seguir um sistema sequencial e hierárquico de "progressão". Podem ter duração variável, e podem, ou não, conceder certificados de aprendizagem. (GADOTTI, 2005, p. 02)

Diante da assertiva acima, inferimos que a diferença básica entre a educação formal e educação não-formal é a formalização burocrática, com diretriz central e curricular que envolve apenas a primeira. Não sendo com isso, a educação não-formal, um evento desorganizado, sem validade, pois o próprio Gadotti (2005, p. 02) assevera que: "a educação não-formal é também uma atividade educacional organizada e sistemática, mas levada a efeito fora do sistema formal”. E para nossa melhor compreensão sobre o assunto, Gohn (2006), define as três formas de educação (formal, não-formal e informal) apontando seu acontecimento cotidiano.

A princípio podemos demarcar seus campos de desenvolvimento: a educação formal é aquela desenvolvida nas escolas, com conteúdos previamente demarcados; a informal como aquela que os indivíduos aprendem durante seu processo de socialização - na família, no bairro, clubes, amigos, etc., carregada de valores e culturas próprias, de pertencimento e sentimentos herdados; e a educação não-formal é aquela que se aprende "no mundo da vida", vias os processos de compartilhamento de experiências, principalmente em espaços e ações coletivos cotidianas. (GOHN, 2006, p. 28)

De acordo com a contribuição dos dois autores, ampliamos nosso entendimento no que tange a educação fora da escola nas organizações civis, passando pelos núcleos religiosos, não se limitando apenas às igrejas paroquiais, mas as diversas instituições e manifestações religiosas pertencentes às sociedades sejam elas de qualquer dimensão. Estando então a educação em toda parte, através da instituição formal e das instâncias não-formais e informais, esta acontece a qualquer momento, independente do tempo e espaço, pois, pode ocorrer nas trocas de experiências, vivências cotidianas, nas inúmeras eventualidades das relações humanas. Todavia, é importante salientar que concebemos a escola, sendo espaço formal de educação, como instituição que pode e deve incluir em seu currículo elementos que viabilize os estudos que fazem parte do 
cotidiano de seus discentes, inclusive, as interações com os saberes de Terreiro, promovendo no mínimo, discussões pertinentes que subtraiam o máximo possível do preconceito relegado à religião Candomblé. Sobre isto temos:

Enquanto instituição, a escola tem o papel de organizar, socializar e transmitir conhecimentos. Em suas diversas dimensões, o patrimônio cultural afrobrasileiro traz possibilidades educativas para as relações étnico-raciais. Desse modo, ele se constitui como uma fonte para a desconstrução da discriminação do negro e sua cultura. Além de que, é um veículo de rompimento da colonização do saber construída pela ótica europeia, a qual historicamente tem imposto relações assimétricas em que os negros são inferiorizados. (CUSTÓDIO, FOSTER, da SILVA, SILVA, 2017, p. 129)

Conforme a afirmativa supracitada se faz pertinente refletir sobre o papel da escola no combate ao preconceito religioso e racial, bem como, embora seja uma instituição formal de ensino, se constitui dentro de comunidades, em que os sujeitos que dela fazem parte, muitas vezes são praticantes de religião afro-brasileira e carrega consigo saberes que certamente contribuirão para discussões de enlevo cultural, favorecendo com isso, o arcabouço de conhecimentos da instituição escolar. Esse adendo se fez oportuno, visto que, consideramos de extrema importância a relação sujeito-escola, e isto repercute os conhecimentos que os sujeitos trazem de suas particularidades.

Continuando nossa reflexão a cerca da educação para além dos núcleos formais, constatando sua ocorrência nos núcleos religiosos, o Candomblé pode estar inserido tanto na educação informal, em que a religião aparece como agente educador, e também na educação não-formal, no qual o educador é "o outro" com quem interagimos e compartilhamos experiências. Veremos que no Candomblé a educação é transmitida através das trocas de informações cotidianas, naturais das relações humanas de seus participantes, sendo, inclusive, uma prática também intencional, na qual há uma finalidade direta de se educar para um pertencimento na doutrina. Quanto a isto, Conrado (s/d) afirma:

Podemos dizer que o Terreiro de Candomblé é um complexo universo de formas, procedimentos éticos, educacionais, estéticos, transcendentais e filosóficos calcados no viver e ser africano, a partir de contribuições de povos de diversas nações aportadas nesse território, deixando para seus descendentes diretos, segredos, lições de vida cuja função é desenvolver a pessoa (CONRRADO, s/d, p. 200). 
O enunciado acima reafirma que a educação pode ocorrer nos diversos espaços onde o ser humano está inserido, nas diversas formas de compartilhamento de aprendizagens. Sobre isto, temos a contribuição de Brandão (2007 p. 13) que assevera: “A educação existe onde não há a escola, por toda parte pode haver redes e estruturas sociais de transferência de saber de uma geração a outra onde ainda não foi sequer criada a sombra de algum modelo de ensino formal centralizado". Diante desta premissa, depreendemos que há um processo educativo no Candomblé, com suas formas peculiares de instruir e educar seus adeptos, oferecendo-lhes um tipo de construção para seu convívio social. Isso ratifica que a educação, está diretamente ligada ao ser humano no seu próprio processo de humanização e em sua integração social, em suas relações com o outro e com o meio. Porém, mesmo atribuindo relevância aos ensinamentos que ocorrem nos Terreiros, não afirmamos que a educação transmitida nesse espaço seja suficiente e definitiva para a formação do sujeito, mas sim, que esta é de grande valia, contribuindo inclusive na formação de valores humanos. Brandão ainda ressalta que:

Ninguém escapa da educação. Em casa, na rua, na igreja, ou na escola, de um modo ou de muitos, todos nós envolvemos pedaços da vida com ela: para aprender, para ensinar, para aprender-e-ensinar. Para saber, para fazer, para ser ou para conviver, todos os dias, misturamos a vida com a educação. (BRANDÃO, 2007, p. 7)

Com a asserção de Brandão, compreendemos que independente da instância educativa, o sujeito receberá ensinamentos que repercutirão por toda sua existência e todas as formas de educação farão parte de sua formação como cidadão, como agente do seu mundo. Isto porque, a educação está nas relações sociais, nas inter-relações entre os sujeitos, nas trocas de saberes, sem, portanto, ser exclusiva de um núcleo social. Assim sendo, iremos encontrá-la em diversos ambientes, inclusive nos grupos religiosos, tal como, o Candomblé.

\section{VALORES E SEU PROCESSO DE CONSTRUÇÃO NO INDIVÍDUO}

A formação de valores no indivíduo se faz natural e imprescindível no seu desenvolvimento e muitas são as instituições não formais que viabilizam tal construção, influenciando na sua inserção e percepções individuais. Podemos encontrar na literatura 
várias abordagens ao termo "valores", todos voltados à quantificação e qualificação de determinado atributo tangível ou intangível. Contudo, o significado de valor que se emprega na formação do ser humano certamente diz respeito à qualidade, préstimo, aquilo que se toma como ideal moral de vida e na sua relação com o meio em que vive. Concebendo, pois, os valores morais como um conjunto das virtudes e princípios humanos.

Muitos pesquisadores observam a respeito do desenvolvimento emocional, social e moral do indivíduo e sobre qual seria a melhor forma de lhes instituir valores desde a sua infância, atributos que sejam válidos por toda a vida. Para Jean Piaget (apud BARROS 2002), crianças pequenas apresentam o realismo moral, ou seja, um ato é bom ou mau, dependendo de suas consequências e não importando as intenções de quem age. A implicação de um ato e a reação/resposta deste é o que a informa se é ou não correto, e direta ou indiretamente os valores morais começam a serem incutidos desta forma no indivíduo desde a infância.

Piaget acredita que a transição do realismo moral para a relatividade moral surge, principalmente, através das interações da criança com seus companheiros, com os quais interage de igual para igual. Os conflitos com os companheiros podem ser resolvidos através de acordos mútuos e recíproca interação, enquanto o poder dos pais sobre a criança torna tal interação recíproca menos desejável em casa (BARROS, 2002, p. 125).

Com base em Piaget, entendemos a importância da interação social na vida da criança e como isso vai repercutir na sua formação moral. É no convívio com a sociedade que a criança vai revelar o aprendizado doméstico e traçar experiências, sendo, então, importante avaliar o comportamento que ela apresenta, para assim entender as suas atitudes. Piaget quando trata de valores, ainda se reporta às questões dos exemplos frisando a relevância deles na formação dos indivíduos: "Com a reciprocidade, cada um valoriza o outro, cada um admira o outro pelo exemplo, comportamento, atitudes, ação" (apud WADSWORTH, 1993).

A criança tende a reproduzir o que lhe é ensinado e, sobretudo o que lhe é exemplificado. É nas interações que o ser humano faz desde a infância (principalmente nesta fase), de troca com o outro e com o meio, que começa a apresentar as influências deste interagir no seu comportamento. Vygotsky (apud PALMEIRA, 2008, p. 133) ressalta: “[...] a criança no seu processo de desenvolvimento, influência o ambiente e a 
si mesma, ao mesmo tempo em que é influenciado por ele". Isto indica que o relacionamento entre os indivíduos é uma maneira de instrução e conduz a construção e difusão de conhecimentos. Por isso mesmo, tem relevância no desenvolvimento emocional, moral e social da criança que se fará adulto e certamente seu comportamento será reflexo de suas experiências. Na educação do Candomblé, por exemplo, essa relação humana se faz cotidiana, em que o aprendizado é processado diariamente, se realizando a todo instante, como ressalva a Ialorixá Stella Santos (2010, p. 102): “Aprender e ensinar são atos constantes da vida. Ensinamos e aprendemos sempre. É importantíssima a transmissão do conhecimento.”.

Como visto até então, as aprendizagens são desenvolvidas pelos indivíduos em suas interações, no relacionamento com o outro e com o meio, inclusive no que diz respeito à sua construção comportamental. Porém, dependendo da comunidade ou grupo na qual a pessoa está inserida, estes padrões podem variar. Contudo, o que se concebe de bom ou mau comportamento moral é um modelo básico a seguir, mas a valoração que se dá a um ato moral depende do contexto histórico e social vivido pelo ser humano, podendo variar de uma sociedade para outra. E não há intenção neste trabalho de qualificar tais valores. Assim conferimos em Heller (1986).

Terão os valores validade universal ou sua validade dependerá de nossas "preferências valorativas"? Que ordem, ou que espécie de valores terão maior validade e importância num determinado momento histórico, para um determinado indivíduo ou grupo social? (HELLER, apud SILVA, 1986, p. 18).

Os questionamentos de Heller, talvez tenham respostas e abordagens múltiplas, dado a diversidade do pensamento e do comportamento humano e o que faz sentido para cada indivíduo e grupo. Tais convicções são particulares, de sua família, escola, religião e outros núcleos sociais. Não havendo nesta investigação qualquer tentativa de aprofundar sobre validade ou qualidade do ato moral.

Variadas são as instituições sociais das quais pertencemos e a moral humana tem diversas características, visto que se relaciona com a ética, com a política, com as crenças religiosas. Entendendo por religião a fé, "a crença na existência de forças sobrenaturais ou em um ser transcendente e sobre-humano, todo-poderoso (ou Deus), com o qual o homem está em relação ou está religado" (VASQUEZ, 2001, p. 89). Assim sendo, as instituições religiosas têm parte relevante na construção/inserção dos valores morais no homem, conduzindo-o moralmente de acordo com seus dogmas, suas 
doutrinas e acaba por influenciar na sua educação, no seu comportamento, na sua visão de mundo, enfim, na sua conduta moral.

Mas, evidentemente, existe uma moral de inspiração religiosa que desempenha também a função de regulamentar as relações entre os homens em consonância com a função da própria religião. Assim, os princípios básicos desta moralamor ao próximo, respeito à pessoa humana, igualdade espiritual de todos os homens, reconhecimento do como pessoa (como fim) e não como coisa (meio ou instrumento) - constituíram, numa determinada fase histórica (particularmente na época da escravidão e servidão feudal), um alívio e uma esperança para todos os oprimidos e explorados, aos quais se negava na terra $\mathrm{o}$ amor, respeito, igualdade e reconhecimento. (VASQUEZ, 2001, p. 91)

Verificando os valores morais a partir dos dogmas religiosos, veremos que seu princípio está em um Ser Supremo, poder superior, no qual todas as virtudes lhe são consequentes. Mesmo diferindo as religiões, existe um modelo universal do Ser Criador, que acaba por influenciar todas as instituições religiosas, independente de como estas lhes dão valoração, ou como passaram os ensinamentos aos seus adeptos. Então, podemos também conceber que os valores podem estar calcados nas crenças religiosas, sendo estas, uma das verdades que participam ou talvez sejam causas primeiras dos padrões morais.

A partir dos ensinamentos ministrados nos templos religiosos, os valores ganham significados, especialmente porque o individuo passa a se identificar com estes, sobretudo por acreditar estar seguindo um padrão único e absoluto de virtudes que têm causa num Ente Superior. Essa crença religiosa que acompanha o homem se intensifica com a necessidade deste de viver numa sociedade justa, respeitosa, e com a ideologia do bem comum, para uma vida melhor. Entendemos então, que as religiões convertem seus integrantes para servirem a determinado propósito, mediante ensinamentos de um Ser Superior. Referente a isto Silva (1986) aponta:

Em Santo Agostinho, por exemplo, o homem se apoia na "lei eterna" para viver bem. Essa lei é o plano do mundo ou da vontade de Deus, portanto, a expressão ideal da ordem do universo. Seu conteúdo, necessariamente coincide com a essência de Deus (a sabedoria divina), da qual emanam os valores morais, estéticos, jurídicos, científicos ou políticos. Deus é o princípio último, a partir dele é que os seres e valores ganham existência e significações (SILVA, 1986, p. 34) 
Conforme a declaração acima, deduzimosque pode o princípio de um padrão moral, dos valores humanos, derivarem da concepção religiosa, do que agrada a determinado criador, independente da personificação que este tenha, dada pelas religiões diversas no mundo. Então, podemos conceber os valores morais e sua inserção no indivíduo como fator orientado, ensinado e/ou exemplificado também ou primeiramente pelas instituições religiosas, que dão direcionamento aos seus adeptos, como faz o Candomblé nos ensinamentos dados aos seus participantes.

Podemos associar ainda, a formação de valores morais à educação, pois, muito da formação de individuo é construído por um processo educativo. Aliás, a formação de valores no ser humano é uma construção do processo educacional. Vasquez (2001), fala sobre o comportamento humano, e consequente a isto nos traz uma abordagem dos valores morais, valores religiosos e da ética. Suas observações abrangem as questões acerca da moral humana, das condutas e posturas adotadas no cotidiano das sociedades, analisando, sobretudo os contextos históricos, filosóficos, políticos que resultam na construção social dos povos.

O comportamento moral não só faz parte de nossa vida cotidiana, é um fato humano entre nós, mas é valioso, ou seja, tem para nós um valor. Ter um conteúdo axiológico (de axios, em grego, valor) não significa somente que consideramos a conduta boa ou positiva, digna de apreço ou louvor, do ponto de vista moral, significa também que pode ser má, digna de condenação ou censura negativa do ponto de vista moral. Em ambos os casos, nós avaliamos ou julgamos como tal em termos axiológicos (VASQUEZ, 2001, p. 135).

Dessa maneira fica evidente o quanto é clara a intencionalidade na formação de valores no indivíduo e que isto acontece já na infância (inevitavelmente), para que este se comporte baseado em um padrão moral comum da sociedade que convive.

\section{CANDOMBLÉ: BREVE HISTÓRICO}

O Candomblé é uma religião de matriz africana que chegou ao nosso território com o tráfico negreiro, pois, os negros escravizados trazidos no período da colonização do Brasil, trouxeram com eles, suas dores, esperanças, fé e crenças. Instituído por uma africana alforriada Iyá Adetá (SETUB-SUSET, 2009) e reelaborado pelos afrobrasileiros, a referida religião teve que contar com a resistência de seus adeptos. Verger (1997, p. 22) pontua: “A presença dessas religiões africanas no novo mundo é 
uma consequência imprevista do tráfico de escravos.”. Resistindo às forças estabelecidas à época, como a Igreja, o Governo e enfrentando dura vigilância da força policial, os praticantes do culto aos Orixástiveram a tenacidade como regra de sobrevivência. Para conquistar o direito à liberdade de cultuar suas divindades, os negros escravos lutaram, e até o fato de camuflarem sua crença junto ao catolicismo era mais uma forma de poder praticar sua fé.

O Candomblé sendo uma religião de negros, herança africana, não era aceito pelo povo catequizado de herança europeia. O caminho até conseguirem cultuar suas divindades ancestraise ter o direito à legalidade de seus cultos foi árduo e demorado. Ainda que a intolerância religiosa exista em dias atuais, foi a resistência dos candomblecistas e a lutapelo direito de professar sua fé que resultou na legalização e institucionalização dos Terreiros de Candomblé.

\footnotetext{
Nascidos na escravidão, sujeitos a implacável perseguição policial até 1976, a partir de quando foram desobrigados, por decreto governamental, de pedir autorização para realizar suas celebrações, esses Candomblés se tornaram no maior centro de resistência e defesa dos valores culturais negro-africanos no Brasil. (CASTRO, 2005, p. 97)
}

A contribuição de Castro nos indica que o Candomblé sofreu e continua sofrendo discriminação, reflexo de uma realidade histórica, que faz com que a cultura negra seja percebida pejorativamente, pois, o ideal eurocêntrico ainda prospera. Siqueira (s/d, p. 66) elucida que "é nesse contexto sociocultural e político que surgem os Terreiros de Candomblé.". Desta forma, podemos entender que o preconceito contra a religião data da chegada forçada e estabelecimento dos africanos no Brasil, em período de colonização, e a estes foram impostos absorverem a crença religiosa europeia. Por este motivo, reforçamos o quanto é importe que os conhecimentos trazidos pelos negros de África, e consequentemente erigidos e perpetuados pela referida religião sejam pontuados na educação humana, especialmente no que tange a luta por uma orientação educacional contra hegemonia, ou seja, no que diz respeito o rompimento da soberania da cultura de determinado povo em detrimento de outro.

Avançando em nosso estudo, seguimos conferindo o estabelecimento da religião de matriz africana no Brasil para melhor compreensão de sua ocorrência e assim entender sua atuação como instituição que educa. Tomando como referencial casuístico, a Bahia, pela importância e dimensão de sua população negra, as primeiras 
manifestações do Candomblé receberam o nome de calundu, que se referia à expressão do africano no momento do transe. Mais tarde passou a ser chamada como conhecemos até os dias atuais, sendo uma adaptação do termo bantu Kandobile, que significa lugar de culto e oração (LODY apud STB-SUSET, 2009, p. 39). Sendo visto de diversas maneiras, o Candomblé é uma religião em que se cultuam, oram, e manifestam as divindades, os Orixás, Inquices e Voduns. Podemos compreender então que o ato de orar e cultuar, (e assim entendemos que se ora a um Ser Sagrado), revela uma religião ritualística, que o próprio significado do nome afirma, como também nos diz Castro (2005, p. 82): “Candomblé, do banto "Kandómbilé>Kandombélé”, ação de rezar, pedir pela intercessão de (os deuses), derivado do verbo "Kundomba>Kulomba", rezar, invocar, está empregado com o sentindo corrente que toma entre seus seguidores".

Tendo então o Candomblé a denominação significativa que confirma a ação de seus adeptos de culto, oração e invocação de deuses, no qual se pede a interferência das divindades no mundo real, torna-lhe uma religião de fé e adoração como as demais existentes no mundo. Aliás, cada religião se processa de forma particular, não sendo tal fato pressuposto de qualificação ou valoração. Assim sendo, na religião de matriz africana, os atos ritualísticos são acima de tudo uma forma de "encontrar-se" com o sagrado, pois, se o próprio nome remete a invocar, pedir interseção das divindades, pressupõe-se a interligação, comunicação com entidades sagradas. Vale ressaltar que para os candomblecistas os ancestrais divinizados permanecem entre nós, fazendo uma ligação entre os humanos e o mundo espiritual, o Orum (céu) e o Aiyê (terra).

Existem também no Candomblé os Sacerdotes conhecidos como Iyalorixá/Doné/Mameto, Babalorixá/Doté, pessoas escolhidas pelas entidades para lhes representarem e passarem seus ensinamentos aos seus seguidores. São estes responsáveis pelas casas, (Terreiros, Ilês, Canzuá, Roças) em que se cultuam as divindades. Tendo ainda os demais integrantes da religião, todos com relevância em seus cargos confiáveis, Ogãs/Huntó, Ekedis/Makotas/Ebomis, pessoas encarregadas pela difusão do conhecimento e funcionamento da religião. Assim, vemos em Castro (2005):

Designa os grupos sociorreligiosos dirigidos por uma classe sacerdotal, cuja autoridade suprema e popularmente chamada de mãe-de-santo ou pai-de-santo, mas recebe mas que recebe o título genético de rumbondo ou rumbono (étmofon) entre as nações Jejes-mina; respectivamente de Iyalorixá ou Babalorixá (étmoyorubá) entre as nações Nagô-Queto; e de nêngua ou tata (étmo banto) entre as nações Congo-Angola (CASTRO, 2005, p. 82). 
Esta religião tem uma forte ligação com a natureza, ou, melhor dizendo, tem por base a ânima (natureza), sendo assim considerada uma religião anímica, que se fundamenta nos elementos naturais. Cada entidade do Candomblé representa um elemento natural, sendo consideradas divindades que são alimentadas, fortalecidas e consagradas pela natureza. Aliás, são a própria natureza manifesta, que se revela espiritualmente se comunicando com os seres humanos. Esse fator é de suma importância, pois, nos mostra que as entidades, espíritos divinizados dos ancestrais africanos são, portanto, sagrados também pela ligação que estabelece com o mundo natural. Então podemos conceber que o Candomblé é a manifestação divina da natureza e das entidades divinizadas, mais que isso, é o encontro com o Deus Supremo ou Olorum para os africanos, com os seres da natureza e a ancestralidade sagrada. A respeito disto, Siqueira (S/D) fala:

Ela se manifesta incorporada aos elementos da natureza: a água, o fogo, a terra, o vento, os búzios, as folhas sagradas, as arvores, o mar, o rio, a chuva, a lama. é pela natureza que permanentemente se realiza e se renova a presença do Deus único no qual o povo de Candomblé acredita. Essa presença chega até os homens pela intermediação dos Orixás. (SIQUEIRA, s/d, p. 66)

A religião Candomblé tem suas peculiaridades a serem conhecidas e assim compreendidas, de modo que pessoas de fora dela devem se despir dos preconceitos para entendê-la rompendo com os estereótipos e estigmas que lhes inferiorizam ou enaltecem, agindo assim com alteridade. Para apreender a religião africana faz-se necessário o entendimento de todas as características próprias desta, ou seja, conhecer a fé que a alimenta, as entidades cultuadas, os significados da sua oralidade, seus códigos, seus elementos.

Outro fator importante é a presença do mito, sendo uma ligação entre a fé e a razão, uma maneira de explicar o invisível, mas existente, a energia intangível e tangível da natureza, o que pode ser visto e o que pode ser apenas sentido. Os mitos são para os adeptos do Candomblé, os seus heróis, seus ancestrais divinizados, seres alcançáveis e possíveis de serem sentidos, deuses que têm relação com a natureza, são próprios da natureza e ligam-se aos humanos, lhes revelando o poder e a vontade de Deus/Olorum, e assim influenciando suas vidas. Nessa relação com o mito, há as simbologias que expressas desde a folha de uma planta (relacionado ao OrixáOssain), um fruto de árvore, o metal (instrumento do Orixá Ogum), os fluxos do mar (resposta do Orixá 
Iemanjá), ou simplesmente a própria certeza que trazem da existência de suas divindades. Santos (2006, p. 161) afirma que "o mito para as comunidades de tradição africana, está presente no seu modo de ver a vida, sendo um elo com outras dimensões da realidade". A autora ainda nos diz:

O mito se concretiza nas histórias, lendas, contos, casos, seja nas orações, nos rituais, nas oferendas, na arquitetura, na vestimenta, no comer, no dizer, no dançar, no cantar, pois o mito não se expressa apenas no discurso linguístico, mas em inúmeras construções textuais que se explicitam, nos vários espaços do fazer humano, através de uma infinidade de forma que a criatividade humana propõe cotidianamente (SANTOS, 2006, p. 162).

O mito de fato tem relevante presença na vida dos candomblecistas. Mais um elemento de grande importância no Candomblé é a oralidade, sendo uma herança africana muito própria, pois os conhecimentos ancestrais são transmitidos através da fala e isto é vivido historicamente na África. Muita atenção é dada ao que é dito, e só é falado o que verdadeiramente tenha valor, para que as palavras façam sentido. A validação de "quem fala" é revestida de magnitude, de tanta relevância quanto o "que fala", a comunicação do individuo é valorado ao extremo. Contudo, o silêncio nas comunicações dos Orixásdiz aos seus adeptos sendo lido e interpretado por estes com clareza, se revelando nas expressões, danças e gestos das entidades. Assim se manifesta o Candomblé, uma religião que nas suas peculiaridades ensina o ser humano a interpretar o mundo e seus fenômenos, vos orientando a viver em comunhão com os dois princípios da vida, o Orun e o Aiyê.

\section{CONHECIMENTOS E PRÁTICAS DO CANDOMBLÉ: EDUCAÇÃO E}

\section{FORMAÇÃO DE VALORES HUMANOS NO COTIDIANO DA RELIGIÃO}

O Candomblé é uma religião peculiar que interpreta a vida através das simbologias, dos mitos, das vivências ancestrais. Há muito mais a ser esclarecido, conhecido, revelado sobre o mundo dos Orixáse dos significativos símbolos que mereceriam uma pesquisa específica, nos limitamos aos pressupostos basilares, dando visibilidade à ligação do referido núcleo religioso com a educação, sendo este o foco principal do nosso estudo. Todavia, faz-se imprescindível esclarecer que os fundamentos contidos no axé não são de todo revelados, pois existem procedimentos mantidos em segredos que somente são transmitidos aos adeptos no decorrer das etapas 
vividas nos Terreiros. Caputo (2012, p. 49) afirma que "um terreiro de Candomblé é constituído de muitos espaços cheios de significados. Em alguns é possível entrar, em outros, não".

São ensinamentos herdados dos ancestrais africanos, lições que, sobretudo revelam respeito, dando início ao que em terras africanas é muito própria, a educação moral, comportamental ou doméstica. Conferimos isto em Stella Santos (S/D, p. 60) que em visita à África percebeu: "Lá os filhos ao amanhecer saúdam os seus pais como nós saudamos aqui os nossos mais velhos. Na Nigéria, os filhos se jogam no chão pedindo a benção. Homens e mulheres repetem cada manhã: "Motumbá". Esta expressão significa inspecione-me".

A referida autora fala com muita propriedade por pertencer à religião, sendo Iyalorixá e por ter conhecido o continente africano, por ter vivenciado lá, essas práticas. Ela faz uma comparação pertinente entre o Candomblé do Brasil com os costumes, cotidianos do povo africano. Mãe Stella Santos (S/D, p. 60) ainda nos revela: "tudo leva a crer que o Candomblé no Brasil foi criado aos moldes da família africana ideal. Foram feitas transferências de hábitos e costumes milenares como sustentáculos para a nossa resistência." Diante desta afirmação começamos a adentrar na educação do Candomblé, começamos a conhecer como se dá o processo educativo nos terreiros.

Entretanto, antes de saber o que é ensinado no Candomblé, como se ensina, se tem alguma metodologia específica, é importante relembrar, para melhor entendimento, a importância da oralidade, sendo uma herança africana. Histórias sobre o continente nos contam sobre a relevância que tem a palavra dita, que para os africanos é divina e sagrada, em uma perspectiva ancestral. Inclusive, o referido povo, concebe a oralidade como uma obra de Deus, tendo a fala uma importância anterior à escrita. Bâ (2003, p.185) assevera que: “A tradição africana, portanto, concebe a fala como um dom de Deus. Ela é ao mesmo tempo divina no sentido descendente e sagrada no sentido ascendente"

É, portanto, através da comunicação oral que todo conhecimento ancestral desde a socialização do homem, vem sendo transmitido entre os africanos. Consequente a isto, dá-se muito valor à fala dos anciões, que tem significativa valoração no Candomblé. São os conhecimentos plurais destes que educa as gerações na África e assim segue prevalecendo nas suas instituições sociais, bem como no Candomblé. E o 
mais importante disto, é que os ensinamentos não se perdem, são absorvidos pelo corpo e pela alma, penetrando as esferas da cognição do ser humano, fazendo-lhes sentido.

A tradição oral é a grande escola da vida, e dela recupera e relaciona todos os aspectos. Pode parecer caótica àqueles que não lhe descortinam o segredo e desconcertar a mentalidade cartesiana acostumada a separar tudo em categorias bem definidas. Dentro da tradição oral, na verdade, o espiritual e o material não estão dissociados. Ao passar do esotérico para o exotérico, a tradição oral consegue colocar-se ao alcance dos homens, falar-lhes de acordo com o entendimento humano, revelar-se de acordo com as aptidões humanas. Ela é ao mesmo tempo religião, conhecimento, ciência natural, iniciação à arte, história, divertimento e recreação, uma vez que todo pormenor sempre nos permite remontar à Unidade primordial (BÂ, 2003, p. 183)

Ao que podemos então compreender, a transmissão oral é um dos primeiros pontos a ser observado na educação plural ministrada no Candomblé. Seguindo a tradição africana, a religião transmite seus conhecimentos, preponderantemente através da fala como esclareceStella Santos (S/D p. 59): "No terreiro a educação é oral, a aprendizagem entra por todos os sentidos, há sempre algo a se aprender principalmente nos momentos de silêncios rituais". O que poderia parecer confuso, ou contraditório, trazao entendimento do que tem de fato valor para o povo de santo, o conhecimento a ser aprendido, o que está sendo revelado pela fala e pelos sentidos, pelas ações e expressões ritualísticas. Sendo religião de matriz africana o Candomblé segue seus princípios e a valorização da palavra, da oralidade tem relação com a valorização que se dá aos mais velhos, pois são estas fontes de saberes preservados e difundidos por entre as gerações.

O respeito à fala está também ligado ao respeito aos ancestrais e aos anciãos, sendo estes, fontes de histórias valorizadas e perpetuadas pelos africanos. Isto indica que os ensinamentos ancestrais são alicerces da constituição das sociedades africanas, bem como as palavras proferidas pelos mais velhos têm importância e veracidade inquestionável para os seus. Por está razão, é dada indispensável atenção aos ancestrais e aos idosos, de forma a cultivar-lhe o conteúdo transmitido e guardar-lhe como tesouro, mas um tesouro aberto a ser compartilhado, uma herança transmitida entre as gerações (ALVES e SANTOS FILHO, 2017, p. 55)

Mediante o enunciado acima fica claro que a tradição oral é uma herança africana que se perpetua no Candomblé. Essa influência diz respeito também aos Griôs, como destaca Machado (s/d, p.112): "A transposição dos mitos para a educação é significativa até pela tradição do Griô. O Griô é um contador de histórias, um modelo de 
mestre ancestral. Ainda hoje, contar história é uma forma de "ensinar" do povo nagô". Essa fala se encaixa exatamente no que concebemos como educação no Candomblé, uma atividade de contação de história, de ensinar através da oralidade, de repassar os conhecimentos adquiridos e de respeito à sabedoria ancestral. Tudo isso inteirado ao exemplo das atitudes, e observação das ações.

A tradição oral sendo a base principal de transmissão dos conhecimentos do Candomblé ensina aos adeptos, educando-os quanto aos procedimentos da religião, sem a utilização de livros, de materiais didáticos que são vistos na escola formal e em outras religiões. Tendo assim uma orientação falada e explicada através do exemplo, exigindo concentração dos iniciados, para que os ensinamentos sejam apreendidos. Isso, aos olhos da educação formal, pode parecer frágil, mas, tais práticas são milenares e vão sendo ministrada cotidianamente, nos afazeres do Terreiro, com resultados consistentes no processo de formação do indivíduo. As falas, conseguem ser reproduzidas em atos e práticas. "Na verdade, o processo de aprendizagem de axé é muito mais complexo, é muito mais difícil do que em uma escola regular. Afinal, não temos programas, nem planejamento e nem escritas. Não temos dogmas nem livros sagrados”. (SANTOS, S/D, p. 58).

No Candomblé os ensinamentos não são apenas dos rituais e conhecimentos próprios da religião, estende-se pelos ensinos aos seus adeptos dos procedimentos adequados para o convívio com o outro, com os que ali chegam. Aprende-se primeiramente o respeito aos mais velhos e consequentemente aos mais novos, num ensinamento de confiança mutua, fazendo das crianças o reflexo dos adultos. Por isso o aprendizado de colaboração, de honra à família, dedicação aos trabalhos no Terreiro e acolhimento aos que procuram a casa de axé, são aprendizados fundamentais para manter a religião. Podemos dizer que essas lições fazem parte da religião, pois no Candomblé só é ensinado o que se acredita e se vive, e tudo isso está ligado aos Orixás, na interpretação que fazem de seus ancestrais, vivendo as lições destes. Isto é para o povo de santo a própria educação.

A cada dia acontece uma lição de vida. Aprende-se tudo, a comunicação com os mais velhos, com os mais novos, o trabalho em grupo fazendo o que gosta e o que não gosta; e, sobretudo aprende-se o gosto pela vida numa estreita relação com o Orixá. (SANTOS, S/D, p.63) 
O respeito é imprescindível no Candomblé, sendo praticado cotidianamente em relação ao próximo e a natureza. $\mathrm{O}$ respeitoàs diferenças, à hierarquização de cargos simbólicos, àutilização dos elementos da natureza, cuidando desta como sua fonte de riqueza natural, e ao ensinar a receber os que chegam aos Terreiros, já revela que há uma espécie de mensagem emblemática, sendo praticada nesses espaços através dos tempos.

Essas práticas podem ser vistas, nos diversos momentos da relação entre seus adeptos com a religião, desde a iniciação por etapas, tendo continuidade nas celebrações e rituais. Nestes momentos são formados valores humanos imprescindíveis para relação do homem com o mundo, e, sobretudo, para autoconhecimento. Então o que é ensinado no Candomblé tem exercício diário, processual, e podemos também dizer hierárquico, pois, os mais velhos na religião são encarregados pela tarefa de orientar os novatos. E entenda-se por mais velhos os que foram iniciados primeiro independentemente da idade cronológica.

Como a iniciação é feita praticamente por etapas: obrigação de três anos, obrigação de sete anos e outros, isto implica numa certa parcimônia do saber. A educação é lenta, entretanto perfeita. $\mathrm{O}$ iniciado é visto como uma criança que cresce e caminha na proteção dos mais velhos tenha este a idade cronológica que tiver. (SANTOS, S/D, p. 60).

Partindo da fala da Iyalorixá Stella Santos entendemos que a educação nos Terreiros começa com o primeiro processo dos seguidores dentro da casa de axé, que é a iniciação. É o momento em que os adeptos se confirmam na religião, aceitando fazer parte dela. Dessa forma começam a receber uma educação plural que não tem os conteúdos da escola formal, não contendo cartilhas ou conteúdos pré-construídos para serem aprendidos, memorizados ou avaliados, nem a presença de um professor formado academicamente. Porém, tem um mestre que se especializou nos conhecimentos e tradições de uma vivência ancestral, que recebeu o mesmo tipo de formação, sendo um transmissor do que aprendeu, no qual a preservação da memória e a oralidade são fundamentais.

Esse momento da iniciação pressupõe o início de um ciclo, ou fase, em que são apresentados ao iniciado os procedimentos básicos sobre a doutrina. Uma fase inclusive de entrega total à religião, um despir-se do que foi vivido para o renascimento em uma nova vida. Processo em que há um isolamento do mundo externo para um efetivo 
contato com o mundo dos ancestrais. $\mathrm{O}$ iniciado experimenta conhecer os fundamentos do Candomblé, é lhe apresentado o mundo das divindades, um mundo de mitos, códigos, rituais, no qual o homem comunga com a natureza e com os ancestrais divinizados. Então, começa aí uma nova vida que Mãe Palmira (apud CAPUTO, 2012, p. 66) revela: 'Iniciar-se no Candomblé significa começar uma nova vida que será inteiramente dedicada ao Órisá. Significa constituir uma nova família. Tudo na vida da pessoa muda, ela ganha inclusive, um novo nome.'.

Essas lições são realizadas inclusive no corpo do iniciado, que passa por uma transformação estética muito forte, de corte da pele, dos cabelos. Educando também no que tange a alimentação, consumando um processo de transmissão de valores e conhecimentos.

A característica fundamental no aprendizado das práticas rituais do Candomblé é o processo iniciático e participante. Durante o período de reclusão nos terreiros ou roças, o noviço passa por uma série de ritos esotéricos (banhos rituais, raspagem de cabeça, etc.) ao mesmo tempo em que começa a adquirir um complexo código de símbolos materiais (substâncias, folhas, raízes, etc.) e gestos, associados a um repertório linguístico específico das cerimônias que se desenvolvem na intimidade dos contextos sagrados de cada território. (CASTRO, 2005, p. 82)

Passando o período de iniciação, o povo do axé segue aprendendo no dia-dia, nos rituais, nas celebrações, tudo que precisa aprender para formar-se no Candomblé. Passam por novas etapas de confirmação na religião, em que inclusive começam a ser preparados para ocupar novas funções hierárquicas dentro da doutrina. Mesmo não tendo chegado à primeira fase de confirmação, os iniciados já são aptos a instruir o que lhe foi instruído, sendo também responsáveis pelos que estão chegando. No Candomblé é efetivo o trabalho de cooperação, de ajuda mútua, pois todos são responsáveis em manter o Terreiro ativo e com bom funcionamento, são dados, portanto, os ensinamentos e a oportunidade de colocar em prática no cotidiano da religião.

Os mais velhos, nesse sentido, são as fontes de sabedoria e ficam com a missão de manter a ordem, a disciplina e ensinar os fundamentos que somente o tempo de vida na religião pode proporcionar. E assim os seguidores dos Orixás vão validando e reafirmando suas crenças, pois, a dedicação dos candomblecistas é o maior instrumento para manter a religião nos nossos dias, resistindo inclusive às várias formas de discriminação que ainda acontecem. 
$\mathrm{Na}$ comunidade cada um tem seu papel bem definido, para desempenhar de acordo com os seus Orixás, cargos ou tempo de iniciação. É uma ordem estabelecida. É a essência da tradição que mantém viva a nossa religião. É a educação de Axé. É a passagem do conhecimento no momento exato. Isso significa dizer que a educação, inclusive a educação doméstica, tradição e hierarquia andam juntas dando sentido à religião dos Orixás. Nossa vida dentro do Axé é totalmente diferente da vida lá fora, e tradição nesse sentido pode ser tomada como sinônimo de resistência. (SANTOS, S/D, p. 59)

Outro ponto importante a ser também observado no Candomblé é a constituição e/ou o fortalecimento do conceito de família, ou ainda a formação de uma nova família. É comum nas religiões o ato de preservação deste núcleo social, há quem acredite que a instituição religiosa é a extensão da instituição familiar. De fato, podemos observar essa crença, se levarmos em consideração o natural sentido de união e solidariedade que permeiam as práticas religiosas em geral. Constatamos que com o Candomblé não é diferente, pois, seus adeptos se relacionam em laços em que fatores como: irmandade, sociedade, comunidade, são atributos naturais para estabelecermos um nível de relação como membros de uma nova família. Tal grupo se aglutina por afinidades, crenças, ideais, que se corporificam respeitando e valorizando seus integrantes enquanto grupo familiar. Por isso mesmo, encontramos nos terreiros o Pai-de-santo (Babalorixá), a Mãe-de-santo (Iyalorixá), Mãe-pequena, Pai-pequeno e os irmãos-de-santo, tendo essa família tanta importância quanto biológica.

Estendendo o conceito de família e assumindo uma maneira de educar, o Candomblé transmite conhecimentos ancestrais aos seus adeptos. Esses ensinamentos são passados pelos mais velhos, considerando uma escala hierárquica respeitada por todos.

Ai das Filhas-de-santo que resolvesse passar por cima da hierarquia, indo queixar-se diretamente com à Mãe-de-santo.... Não tinha nem graça! O grupo de Âgba, a que me referi, tinha que educar as iniciadas. Casos estas não se comportassem muito bem, a culpa era atribuída à incompetência das mestras. $\mathrm{O}$ Professor responde pelos seus discípulos, não é assim mesmo? Daí o zelo das Àgba em transmitir conhecimentos aos mais novos. Conhecimentos estes que, por sua vez, elas tinham recebido dos mais velhos. (SANTOS, 2010, p. 21)

Muitos estudos foram feitos ao longo dos tempos por autores que já reconhecem as práticas das religiões de matrizes africanas, como contribuintes para formação social e educacional do ser humano. Como exemplo, temos Vanda Machado que conviveu no Terreiro Ilê Axé Opô Afonjá durante meses, para vivenciar as ações ocorridas no referido local e que resultou no livro "Ilê Axé - Vivências e invenção pedagógica: As 
crianças do Opô Afonjá", no qual ela relata a rica experiência que pode viver na referida comunidade.

No decorrer do seu relato Vanda Machadodescreve as práticas e ações de que teve conhecimento no Candomblé, e principalmente as trocas de experiência que viveu com as crianças do Opô Afonjá. Ela nos conta o aprendizado que teve com uma espécie de lição sobre o inhame, elemento essencial da referida religião. Nesse episódio, a autora ganhou de lembrança da festa de Oxóssi, uma raiz de inhame, ela resolveu levála para as crianças do terreiro, para fazer uma atividade pedagógica e constatou que o alimento também tem sentido simbólico para elas, que está diretamente ligado com a natureza: "No Candomblé, o sentido de comer é também simbólico. E de certo modo é um ato ritual, desde quando acredita-se tratar de uma troca de energia” (1999, Pág. 101).

Foi tomada pela emoção das crianças que eu, a cada momento, caminhei para a perspectiva de uma aprendizagem menos sofrida, menos suscetível de gerar atividades egocêntricas em que o aproveitamento da sabedoria intuitiva, característica da cultura afro-brasileira, se constitui uma base receptora e conciliadora das experiências do grupo estudado [...] (MACHADO, 1999, Pág. 103).

Quando Vanda nos relata a atividade que propôs às crianças do Opô Afonjá, de certa forma ela já nos afirma que é possível aproveitar os conhecimentos ancestrais transmitidos pelo Candomblé e suas crenças, para fazer intervenções pedagógicas de grande valia, sendo feita ou não na educação formal. É o aproveitamento de algo que faz parte do cotidiano e vivências dessas crianças (exemplo da autora), para que assuntos sejam abordados claramente por fazer parte da vida delas, acontecendo o ensino-aprendizagem.

Além de Mãe Stella Azevedo e Vanda Machado, outros nomes fazem parte da lista de estudiosos que abordam as práticas vividas nas religiões de matrizes africanas. Dentre eles, temos Ruy Póvoas (2007, Pag. 21), que relata sua experiência no Candomblé como iniciado, e como educando do Terreiro. Este, diz que as experiências que tem vivido no Candomblé são incontáveis, recebendo número considerável de pessoas no Terreiro, na sua condição de Babalorixá.O autor se refere ao cargo que exerce e que lhe possibilita receber os visitantes da sua casa de axé, lhes acolhendo e oferecendo ajuda no que lhe compete.

Para mim, este exercício tem sido fonte de muita alegria e realização, por ajudar a um número bastante considerável de pessoas. Tocar as feridas da alma 
humana tem sido para mim causa de muita dor. No terreiro estou sob votos de palavra. Eu não faço o que eu quero. Tudo segue conforme a vontade do Orixá, dentro dos três princípios que regem o Candomblé: Preceito, Respeito, Segredo. (PÓVOAS, 2007, P. 21)

Acolhimento parece ser a palavra de ordem nos Terreiros de Candomblé, e saber acolher o mundo com sua diversidade é traço peculiar da religião. Com o relato de Póvoas, fica implícito que não há uma distinção de quem vai ser aceito no culto aos Orixás, não se indaga a origem, e fica explicito que o importante é recebê-la, já lhe oferecendo uma ajuda caso tenha necessidade. Para Siqueira (S/D, p.67), "as pessoas buscam e encontram no Candomblé esperança e solidariedade que lhes são negadas no cotidiano da vida". Isso significa oferecer fé no sagrado, confiança no outro, mostrar que ainda existem pessoas com quem se pode contar. Dessa maneira, ensinando o exercício da caridade, do bem-fazer ao próximo, do respeito às diferenças, nas práticas cotidianas, o Candomblé contribui para a formação dos valores, educando seus adeptos a harmonizarem-se com o mundo.

Lembremos ainda, que todos os procedimentos no Candomblé estão pautados na crença que se tem nos Orixás, na relação de devoção, de fé que os seus adeptos têm com seus ancestrais divinizados. Os mitos, os seres sagrados, a crença numa natureza viva que se manifesta através da comunicação com os Orixáse nos ritos, são fatores essenciais para que os seguidores da religião continuem comungando da mesma relação com a imaterialidade. Sem a fé nessa união Orum-Ayê, e a entrega que eles se permitem já nos primeiros passos da iniciação, os trabalhos nas casas de axé ficariam dispersos, sem consistência. A ligação homem-Orixá é a mola propulsora para que a religião seja realizada.

A relação Ser Supremo, natureza, Orixás, homens se corporifica no Terreiroespaço mítico social, espiritual e comunitário onde mãe ou pai de santo, filhas de santo, mogbás, ogans, ekedis se reúnem para a realização de suas práticas rituais e trocas simbólicas. A estrutura do Terreiro obedece a uma hierarquia, por natureza participativa e solidária. (MUNANGA apud SIQUEIRA, S/D, p. $67)$.

O Candomblé é, pois, uma religião construída na crença em forças sobrenaturais, energias sagradas que se revelam no trato de seus adeptos com os outros. Acredita-se que após a iniciação, o sujeito recebe um fortalecimento espiritual que vai sendo alimentado no cotidiano. É uma espécie de poder que anima seus adeptos, conduzindo 
suas vidas, transmitindo-lhes o que é próprio dos Orixáse dos elementos da natureza, que estes, denominam axé."Tanto para um adulto como para uma criança, o elemento mais precioso do Terreiro é o Àse (força, poder, energia). Ele realimenta e coloca tanto o sistema religioso coletivo quanto a vida individualizada da pessoa em movimento." (CAPUTO, 2012, 72). Esse axé está presente na educação de Terreiro, essa força espiritual que advém dos Orixás também orienta os candomblecistas fazendo parte do universo peculiar da religião de matriz africana.

São muitas as lições a serem observadas nos Terreiros, que implica uma educação peculiar do Candomblé. Na religião tudo se baseia na relação com os Orixás, na crença da existência destes, e conforme essa ligação com os ancestrais, tudo que foi aprendido pelos mais velhos é retransmitido aos novatos. Lembrando que não há escritos para ensinar os preceitos dessa religião, nem professores específicos para isto. A educação se processa a partir da transmissão oral e das práticas.Já os educadores são as pessoas sabedoras do axé, das leis que regem o mundo, dotadas de fé na existência de Seres supremos, e que por Eles, vivem na base do respeito, da humildade, da resistência e da cooperação com o Orun e o Aiyê.

\section{CONSIDERAÇÕES FINAIS}

Existem alguns processos educacionais que fogem ao crivo da escola e que são de importância fundamental na formação de um indivíduo. Vimos aqui, lições baseadas nas práticas das religiões de matrizes africanas, mais propriamente o Candomblé, que tem uma inter-relação especial com a natureza, repercutindo nos seus adeptos, agregando valores na formação destes, que contribuem no processo de educação.Parte disse reflete que ainda existem atividades de culturas estigmatizadas não são encaradas com o devido valor dentro da cultura escolar.

Quando o Candomblé transmite lições de respeito à natureza, ao próximo e às hierarquias, independentemente da idade dos indivíduos e, sobretudo quando oferece atos de solidariedade aos que vão ao seu encontro, está sem dúvida alguma, educando a partir da conscientização e sendo alicerçado pelos valores humanos. Tais atitudes contribuem significativamente para ao processo de educação.

Contudo, observamos que ainda há uma resistência por parte da sociedade e até mesmo das instituições formais da educação, em reconhecer práticas doCandomblé que 
possam favorecer o processo educativo do ser humano. O planejamento formal não consegue ou não queridentificar atividades que reforcema emergência e pluralidade no processo de aprendizagem.

O risco do fundamentalismo dentro do contexto do aprendizado é justamente o de suprimir determinadas culturas, diversas e tão importantes, no ato do processo educativo. Isso limita o saber dos educandos e de certa forma favorece o preconceito. Quando ao contrário, deveria fazer parte do planejamento pedagógico o estudo do homem em sua totalidade, mostrando sua diversidade e seus valores. Agregando assim, um estudo igualitário, no qual toda a comunidade escolar seria integrada, e os próprios educandos se sentiriam como parte do estudo.

Todavia, sabemos que ainda há uma resistência no que diz respeito ao Candomblé e mesmo as esferas escolares ainda não comungam com a ideia de oferecer educação livre de fundamentalismos e preconceito. Por esta razão, nosso trabalho tenta contribuir com uma visão acerca do Candomblé que o desmistifique. Concebemos que falar sobre Instituições estigmatizadas de maneira respeitosa, conhecendo sua realidade, é a chave para abrir as portas de uma educação que ainda se faz excludente.

Tendo entrado nas esferas dos valores humanos e da educação, verificamos como surgem na vida humana e como vêm se processando ao longo dos tempos, evoluindo juntamente com os grupos sociais. Esses fatores acompanham os indivíduos, sendo muitas vezes determinantes e influenciadores em seus comportamentos. E isto se deve às formas com que são transmitidas as convicções, concepções e saberes dos diversos povos existentes no mundo. Mas, como tomamos o Candomblé como foco da nossa pesquisa, conferimos aqui, suas práticas, exemplos e ensinamentos ajudam na formação dos valores dos seus adeptos, repercutindo também na comunidade em que está inserido.

Conferimos que a oralidade é uma das características de forte apelo nas comunidades africanas e assim sendo, também no Candomblé, pois, a palavra é para seu povo um dos instrumentos que promove as relações, sendo até mesmo sagrada, como nos disse Bâ (2003, p. 185). Os ensinamentos transmitidos pela religião de matriz africana não se encontram exclusivamente em escrituras, não há cartilhas, apenas se baseiam na crença construída nos ancestrais divinizados, e na fala de seus mais velhos de sua comunidade. Em um processo que talvez pareça contraditório, os iniciados do Candomblé também absorvem conhecimentos através do silêncio, se relacionando com 
a natureza e com os Orixás, fazendo valer uma comunicação oral e silenciosa, mas, sobretudo, expressiva.

Percebemos que a religião de matriz africana teve que contar com a resistência de seu povo, para continuar existindo nos dias atuais, ganhado espaço na sociedade, enfrentando os diversos tipos de preconceitos a que sofreu. Vimos também, que o Candomblé é pouco abordado nas instituições formais de ensino, o que acaba limitando as discussões sobre a diversidade cultural que há em nosso país. Quanto a isto, Siqueira (2006, p. 167) fala: "A educação brasileira não pode mais ignorar outras perspectivas educacionais que há tanto tempo permeiam nosso território cultural".

A importância que tem a educação deve estar ligada a outro fator importante na nossa sociedade: a diversidade cultural. Ou seja, devem ser levadas em consideração, as peculiaridades sociais que permeiam a escola e atodo o tecido social, de maneira ampla e diversa. E isto implica em absorver as contribuições que o Candomblépode oferecer à própria educação.

Diante do que foi exposto nesta pesquisa, ganhamos conhecimentos que nos ajudarão compreender melhor o Candomblé e a educação, mesmo tendo muito ainda a ser revelado, não se esgotando aqui. Bem como, seremos levados a refletir sobre a herança que nos foi deixada pelos africanos, com a qual muitas vezes nos identificamos ou negamos, verificando se há em nós atitudes que valorizem tais contribuições ou as negue. Acreditamos que o fato de todo o processo de difusão do conhecimento pode ser balizado pela transmissão oral e ainda assim ter rigor a ganhos pedagógicos.O sistema formal assumiu há muito o rigor da escola formal e sua tradição acadêmica eurocêntrica, os valores da ciência moderna, que resiste a oralidade e a emergência na construção do conhecimento, conceitos cada vez mais recorrentes nas experiências modernas de construção do processo de educação.

\section{REFERÊNCIAS}

ALVES, Janaína Bastos; SANTOS FILHO, E. F. A Tradição Oral para povos africanos $e$ afrobrasileiros: relevância da palavra. IN: Revista da ABPN, v. 9, Ed. Especial - Caderno Temático: Saberes Tradicionais, 2017, p. 50-76.

BÂ, Amadou Hampâté. Amkoullel, o menino fula. Tradução Xina Smith de Vasconcellos. São Paulo: Palas Athena: Casa das Áfricas, 2003.

BAHIA. Secretária de Turismo. Superintendência de Serviços Turísticos - SUSET. Turismo Étnico-Afro na Bahia. / A Secretária _ Salvador: Fundação Pedro Calmon, 2009. 
BARROS, Célia Silva Guimarães. Pontos psicológicos do desenvolvimento. São Paulo: Editora Ática, 2002.

BRANDÃO, Carlos Rodrigues. O que é educação? São Paulo - SP; Editora Brasiliense, 2007.

CAPUTO, Stela Guedes. Educação nos terreiros: e como a escola se relaciona com as crianças de Candomblé. 1 ed. - Rio de Janeiro: Pallas, 2012.

CASTRO, Yeda Pessoa de. Falares africanos na Bahia (um vocabulário afro brasileiro). 2 ed. Rio de Janeiro: ABL TOPBOOKS, 2005.

CONRADO, Amália Vitória de Souza. Simbologia Corporal do Candomblé: um caminho para a concepção de corpo na visão afrobrasileira. In: BOAVENTURA, Edvaldo M. e SILVA, Ana Célia da. $O$ Terreiro, a quadra e a roda: formas alternativas de educação da criança negra em Salvador. - Salvador. Programa de pós-graduação em educação - UFBA, s/d.

FOSTER, Eugénia da Luz Silva; SILVA, Alene Chagas da; SILVA, Ana Cristina Rocha; CUSTÓDIO, Elivaldo Serrão. Religião e patrimônio: a apropriação do patrimônio cultural imaterial de Mazagão Velho-AP pela escola. Revista da ABPN, v. 9, Ed. Especial - Caderno Temático: Saberes Tradicionais, 2017, p.127-15.

FREIRE, Paulo. Educação como prática da liberdade. Rio de Janeiro: Paz e Terra, 1999.

GADOTTI, Moacir. A questão da educação formal/ não-formal. L'éducationcontrel'éducation: l'oubli de l'éducation au traversed L'Education Permanente.Lausanne: Ed. L'Age d'Homme, 2005.

GOHN, Maria da Glória. Educação não formal, participação da sociedade civil e estruturas colegiadas nas escolas. Ensaio: aval. pol. públ. Educ., Rio de Janeiro, v.14, n.50, 2006, 27-38.

HOUAISS, Antônio; VILLAR, Mauro de Salles. Dicionário Houaiss de língua portuguesa. elaborado pelo Instituto Antônio Houaiss de Lexicografia e Banco de Dados da Língua Portuguesa S/C Ltda. 1.ed. - Rio de Janeiro: Objetiva, 2009.

MACHADO, Vanda. Ilê Axé: Vivências e Invenção Pedagógica - As crianças do Opô Afonjá. Salvador, Editora da Universidade Federal da Bahia, 1999.

Projeto Irê Ayo - Em busca de uma pedagogia nagô. In: BOAVENTURA, Edvaldo M. e SILVA, Ana Célia da. O terreiro, a quadra e a roda: formas alternativas de educação da criança negra em Salvador. - Salvador: Programa de Pós-Graduação em Educação UFBA, s/d.

PALMEIRA, Maria José de Oliveira. Educação e democracia: fundamentos teóricos para uma abordagem dos valores. organizado por Maria José de Oliveira Palmira, Nilson Antônio Ferreira Roseira - Salvador, EDUNEB, 2008.

PIAJET, Jean. A formação do símbolo na criança, Imitação, jogo e sonho, imagem e representação. Tradução: Álvaro Cabral e Cristiano Monteiro Oiticica: RJ, Editora Zahar, 1978. Para onde vai a educação? Tradução: Ivete Braga - 14 ed. - Rio De Janeiro: José Olímpio, 1998.

PÓVOAS, Ruy do Carmo. Da porteira pra fora: Mundo de preto em terra de branco. Ilhéus, Editus, 2007. 
SANTOS, Maria Consuelo Oliveira. A dimensão pedagógica do mito: Um estudo no Ilê Axé Ijexá. Livro: Imagens negras: ancestralidade, diversidade e educação. Belo Horizonte: Mazza Edições, 2006.

SANTOS, Maria Stella de Azevedo. Meu tempo é agora. $2^{\mathrm{a}}$ edição; Assembleia Legislativa do Estado da Bahia, 2010.

Fé e Cidadania. In: BOAVENTURA, Edvaldo M. e SILVA, Ana Célia da. O terreiro, a quadra e a roda: formas alternativas de educação da criança negra em Salvador. - Salvador: Programa de Pós-Graduação em Educação UFBA, s/d.

SILVA, Sonia Aparecida Inácio. Valores em educação. Petrópolis. Rio de Janeiro: Editora Vozes, 1986.

SILVEIRA, Marialda Jovita. A educação pelo silêncio: o feitiço da linguagem no Candomblé. Ilhéus, BA: Editus, 2004.

SIQUEIRA, Maria de Lourdes. Imagens negras: ancestralidade, diversidade e educação. Belo Horizonte: Mazza Edições, 2006.

A Força que anima. In: BOAVENTURA, Edvaldo M. e SILVA, Ana Célia da. O terreiro, a quadra e a roda: formas alternativas de educação da criança negra em Salvador. Salvador: Programa de Pós-Graduação em Educação UFBA, s/d.

VASQUEZ, Adolfo Sanchez. Ética. Tradução: Dele Anna; RJ: Civilização Brasileira, 2001.

WODSWORTH, Barry J. Inteligência e afetividade da criança na teoria de Piaget. Tradução: Esméria Ravai: São Paulo, Livraria Pioneira Editora, 1993.

Recebido 30/03/2020

Aprovado em 30/04/2020 